\title{
TINGKAT STRES DENGAN PENINGKATAN KADAR GULA DARAH PENDERITA DIABETES MELLITUS
}

\author{
Level of Stress with Increasing Blood Sugar Concerning Diabetes Mellitus \\ Difran Nobel Bistara, Chilyatiz Zahroh, Erika Martining Wardani \\ Universitas Nahdlatul Ulama Surabaya \\ nobel@unusa.ac.id
}

\begin{abstract}
ABSTRAK
Diabetes Mellitus merupakan salah satu penyakit kronik yang memerlukan waktu perawatan lama, pembiayaan perawatan yang sangat mahal, selain itu prevalansi diabetes milletus juga meningkat. Keharusan penderita diabetes mellitus dalam mengubah pola hidupnya agar gula darah dalam tubuh tetap seimbang dapat mengakibatkan mereka rentan terhadap stress. Stress pada penderita diabetes mellitus dapat mengakibatkan gangguan pada pengontrolan kadar gula darah. Tujuan penelitian untuk mengetahui adanya hubungan tingkat stress dengan kadar gula darah pada penderita Diabetes Mellitus. Penelitian ini menggunakan metode analitik observasional dengan pendekatan cross sectional dengan sampel berjumlah 45 responden penderita Diabetes Melitus di wilayah RW 7 Kelurahan Simokerto Kecamatan Simkerto Surabaya yang diambil dengan teknik simple random sampling. Pengukuran tingkat stress menggunakan kuesionar. Kadar gula darah diperoleh dari observasi menggunakan glucometer secara acak. Data dianalisis dengan menggunakan uji korelasi spearman rank. Hasil uji korelasi spearman rank didapatkan nilai $\mathrm{p}=0,00$ dan $\mathrm{r}=0,909$. Hal ini semakin tinggi tingkat stress yang dialami akan semakin tinggi pula nilai kadar gula darah. Saran untuk peniliti selanjutnya adalah dapat meniliti factor lain yang dapat mempengaruhi kadar gula darah, serta untuk melakukan observasi perilaku stress agar hasil lebih valid.
\end{abstract}

Kata Kunci: Diabetes Melitus, Tingkat Stress, Kadar Gula Darah

\begin{abstract}
Diabetes Mellitus is one of the chronic diseases that require long maintenance time, the cost of care is very expensive, besides the prevalence of diabetes milletus also increased. The need for people with diabetes mellitus in changing their lifestyle to keep blood sugar in the body remain balanced can make them vulnerable to stress. Stress in people with diabetes mellitus can lead to disruption in blood sugar control. The purpose of the study to determine the relationship of stress levels with blood sugar levels in patients with Diabetes Mellitus. This study used observational analytic method with cross sectional approach with a sample of 45 respondents of Diabetes Mellitus in RW 7 Simokerto District Simkerto Surabaya, taken by simple random sampling technique. Measurement of stress levels using questionnaires. Blood sugar levels were obtained from observations using a glucometer at random. Data were analyzed by using spearman rho correlation test. Spearman rank correlation test results obtained $p$ value $=0.00$ and $r=0.909$. The higher the level of stress experienced will be the higher the value of blood sugar levels. Suggestions for the next researcher are able to investigate other factors that can affect blood sugar levels, as well as to observe stress behavior for more valid data.
\end{abstract}

Keywords: Diabetes Mellitus, Stress Level, Blood Sugar Level.

\section{PENDAHULUAN}

Diabetes Mellitus (DM) dengan komplikasi cukup besar dikatakan sebagai salah satu masalah nasional yang harus mendapat perhatian lebih. DM merupakan penyakit kronik yang memiliki prevalensi cukup tinggi dan memerlukan pembiayaan yang mahal dan perawatan yang cukup lama ${ }^{1}$ Kestabilan kadar gula darah harus terus dilakukan oleh penderita diabetes mellitus. Hal ini dimaksudkan untuk menjaga keseimbangan pola hidup agar tidak terjadi stress karena tuntutan situasi yang harus 
dijalankan tidak sesuai dengan sumber daya yang dimiliki. Stres akan terjadi apabila tuntutan situasi dirasakan terlalu berat dibandingkan situasi sebelumnya ${ }^{2}$.

Data Riset Kesehatan Dasar (Riskesdas) di Indonesia terdapat 17,9 juta orang yang beresiko menderita diabetes mellitus dan terdapat 10 juta orang yang mengalami diabetes mellitus. Provinsi Jawa Timur menjadi provinsi dengan penderita diabetes mellitus terbesar ke 10 di Indonesia dengan prevalensi 6,8. Factor pola makan yang salah, factor keturunan, kurangnya aktivitas fisik, kehamilan, perubahan gaya hidup, perokok, obesitas, obat-obatan dan stress merupakan factor yang dapat meningkatkan jumlah penderita Diabetes Melitus ${ }^{3}$.

Dampak psikologis dari Diabetes Melitus mulai dirasakan oleh pasien terdiagnosis Diabetes Melitus dan penyakitnya telah berlangsung selama beberapa bulan. Pasien mulai mengalami gangguan psikis diantaranya stres pada dirinya sendiri berkaitan dengan pengobatan yang dijalani ${ }^{5}$. Stres telah menjadi salah satu faktor yang muncul pada penderita Diabetes Melitus. Stres adalah respon tubuh yang tidak spesifik terhadap setiap kebutuhan tubuh yang terganggu, suatu fenomena universal yang terjadi dalam kehidupan seharihari dan tidak dapat dihindari, setiap orang mengalaminya. Stres dapat berdampak secara total pada individu yaitu terhadap fisik, psikologis, intelektual, sosial dan spiritual, stres dapat mengancam keseimbangan fisiologis. Stres emosi dapat menimbulkan perasaan negatif atau destruktif terhadap diri sendiri dan orang lain. Stres intelektual akan mengganggu persepsi dan kemampuan seseorang dalam menyelesaikan masalah, stres sosial akan mengganggu hubungan individu terhadap kehidupan 6 .

Penelitian menunjukkan bahwa stress memberi kontribusi 50 sampai 70 persen terhadap timbulnya sebagian besar penyakit seperti penyakit kardiovaskuler, hipertensi, kanker, penyakit kulit, infeksi, penyakit metabolic dan hormone, serta lain sebagainya. Ketika seseorang mengalami stress yang berat, akan memperlihatkan tanda-tanda mudah lelah, sakit kepala, hilang nafsu, mudah lupa, bingung, gugup, kehilangan gairah seksual, kelainan pencernaan dan tekanan darah tinggi.

Namun perlu ditekankan disini, stress tidak selamanya membuat orang menjadi tidak waras sehingga terpaksa harus berada di rumah sakit jiwa. Karena stress mempunyai beberapa tingkatan. Jadi selama individu tersebut masih mengalami stress yang ringan, maka individu tersebut hanya akan sering memikirkannya dan berusaha untuk memecahkan masalah yang menjadi penyebab stress. Orang hidup tidak mungkin terhindar dari stress untuk itu kita harus dapat menyikapi dan mengelola stress dengan baik sehingga kualitas hidup kita menjadi lebih baik.

Oleh sebab itu, peneliti tertarik untuk melakukan penelitian dengan judul "Hubungan tingkat stres dengan kadar gula darah pada penderita Diabetes Mellitus."

\section{METODE}

Desain yang digunakan dalam penelitian ini adalah korelasional (hubungan/asosiasi) dengan pendekatan metode cross sectional. Penelitian dilakukan pada tanggal 19 - 31 Maret 2018 di RW 7 Kelurahan Simokerto Kecamatan Simokerto Surabaya. Populasi dalam penelitian ini adalah seluruh penderita DM yang rutin kontrol kurang lebih satu bulan sekali di puskesmas dan rutin minum obat di Kecamatan Simokerto Kelurahan Simokerto Surabaya dengan sampel sejumlah 45 orang. Teknik sampling yang digunakan dalam penelitian ini Simple Random Sampling. Analisa yang digunakan adalah uji statistic korelasi Spearman Rho. Uji Spearman Rho adalah uji statistic yang digunakan untuk menguji signifikansi asosiatif dan mencari hubungan bila masing-masing variabel yang dihubungkan berbentuk ordinal ${ }^{8}$.

\section{HASIL PENELITIAN}

1. Karakteristik Responden Berdasarkan Jenis Kelamin

Tabel 1 Distribusi Jenis Kelamin di Wilayah RW 7 Kelurahan Simokerto Kecamatan 
Simokerto Surabaya pada tanggal $19-31$ Maret 2018

\begin{tabular}{cccc}
\hline No & Jenis Kelamin & Jumlah & Persentase \\
\hline 1 & Laki-laki & 16 & $35 \%$ \\
2 & Perempuan & 29 & $65 \%$ \\
\hline & Jumlah & 45 & $100 \%$ \\
\hline
\end{tabular}

Berdasarkan Tabel 1 menunjukan sebagian besar responden di wilayah RW 7 Kelurahan Simokerto Kecamatan Simokerto Surabaya berjenis kelamin perempuan berjumlah $29(65 \%)$.

2. Karakteristik Responden Berdasarkan Usia Tabel 2 Distribusi Usia Kelamin di Wilayah RW 7 Kelurahan Simokerto Kecamatan Simokerto Surabaya pada tanggal 19 - 31 Maret 2018

\begin{tabular}{cccc}
\hline No & Usia & Jumlah & Persentase \\
\hline 1 & $18-$ 30 Tahun & 4 & $8 \%$ \\
2 & $30-50$ Tahun & 19 & $43 \%$ \\
3 & $>50$ Tahun & 22 & $49 \%$ \\
\hline & Jumlah & 45 & $100 \%$ \\
\hline
\end{tabular}

Berdasarkan Tabel 2 menunjukan hampir sebagian besar responden di wilayah RW 7 Kelurahan Simokerto Kecamatan Simokerto Surabaya berusia $>50$ Tahun sejumlah 22 (49\%).

3. Karakteristik Responden Berdasarkan Pendidikan Terakhir

Tabel 3 Distribusi Pendidikan Terakhir di Wilayah RW 7 Kelurahan Simokerto Kecamatan Simokerto Surabaya pada tanggal 19-31 Maret 2018

\begin{tabular}{cccc}
\hline No & Pendidikan & Jumlah & Persentase \\
\hline 1 & SD & 12 & $27 \%$ \\
2 & SMP & 7 & $15 \%$ \\
3 & SMA & 21 & $47 \%$ \\
4 & S1 & 5 & $11 \%$ \\
\hline & Jumlah & 45 & $100 \%$ \\
\hline
\end{tabular}

Berdasarkan Tabel 3 menunjukan hampir sebagian besar responden di wilayah RW 7 Kelurahan Simokerto Kecamatan Simokerto Surabaya berpendidikan terakhir SMA sejumlah $21(47 \%)$.

\section{Karakteristik Responden Berdasarkan Pekerjaan}

Tabel 4 Distribusi Pekerjaan di Wilayah RW 7 Kelurahan Simokerto Kecamatan Simokerto Surabaya pada tanggal 19 - 31 Maret 2018

\begin{tabular}{cccc}
\hline No & Pekerjaan & Jumlah & Persentase \\
\hline 1 & Pegawai Negeri & 10 & $22 \%$ \\
2 & Swasta & 21 & $47 \%$ \\
3 & Wiraswasta & 6 & $13 \%$ \\
4 & Tidak Bekerja & 8 & $18 \%$ \\
\hline & Jumlah & 45 & $100 \%$ \\
\hline
\end{tabular}

Berdasarkan Tabel 4 menunjukan hampir sebagian besar responden di wilayah RW 7 Kelurahan Simokerto Kecamatan Simokerto Surabaya memiliki pekerjaan swasta sejumlah $21(47 \%)$.

5. Karakteristik Responden Berdasarkan Lama Menderita Diabetes Mellitus

Tabel 5 Distribusi Lama Menderita di Wilayah RW 7 Kelurahan Simokerto Kecamatan Simokerto Surabaya pada tanggal 19 - 31 Maret 2018

\begin{tabular}{cccc}
\hline No & Lama Menderita & Jumlah & Persentase \\
\hline 1 & $<1$ Tahun & 9 & $20 \%$ \\
2 & $1-5$ Tahun & 24 & $53 \%$ \\
3 & $>5$ Tahun & 12 & $27 \%$ \\
\hline & Jumlah & 45 & $100 \%$ \\
\hline
\end{tabular}

Berdasarkan Tabel 5 menunjukan sebagian besar responden di wilayah RW 7 Kelurahan Simokerto Kecamatan Simokerto Surabaya lama menderita Diabetes Mellitus sekitar 1 - 5 tahun sejumlah 24 (53\%).

\section{Data Khusus}

1. Distribusi Frekuensi Responden Berdasarkan Kadar Gula Darah

Tabel 6 Distribusi Kadar Gula Darah Pada Penderita Diabetes Mellitus di Wilayah RW 7 Kelurahan Simokerto Kecamatan Simokerto Surabaya pada tanggal 19-31 Maret 2018

\begin{tabular}{cccc}
\hline No & Kadar Gula & Jumlah & Persentase \\
\hline 1 & Hipoglikemia & 3 & $7 \%$ \\
2 & Normal & 19 & $42 \%$ \\
3 & Hiperglikemia & 23 & $51 \%$ \\
\hline & Jumlah & 45 & $100 \%$ \\
\hline
\end{tabular}

Berdasarkan Tabel 6 menunjukan bahwa distribusi frekuensi responden berdasarkan variable kadar gula darah di Wilayah RW 7 Kelurahan Simokerto Kecamatan Simokerto Surabaya sebagian dari responden nilai kadar gula darah dalam kategori hiperglikemia dengan jumlah 23 responden (51\%).

2. Distribusi Frekuensi Responden Berdasarkan Tingkat Stres 
Tabel 7 Distribusi Kadar Tingkat Stress Pada Penderita Diabetes Mellitus di Wilayah RW 7 Kelurahan Simokerto Kecamatan Simokerto Surabaya pada tanggal 19-31 Maret 2018

\begin{tabular}{cccc}
\hline No & Tingkat Stres & Jumlah & Persentase \\
\hline 1 & Tidak Stres & 22 & $49 \%$ \\
2 & Stres Ringan & 9 & $20 \%$ \\
3 & Stres Sedang & 11 & $25 \%$ \\
4 & Stres Berat & 3 & $6 \%$ \\
\hline & Jumlah & 45 & $100 \%$ \\
\hline
\end{tabular}

Berdasarkan Tabel 7 menunjukan bahwa distribusi frekuensi respnden berdasarkan variable tingkat stres di Wilayah RW 7 Kelurahan Simokerto Kecamatan Simokerto Surabaya sebagian dari responden memiliki tingkatan stress dengan kategori tidak stres dengan jumlah 22 responden (49\%).

3. Hubungan Data Variabel Tingkat Stres dengan Data Variabel Kadar Gula Darah pada Penderita DM

Tabel 8 Hubungan Tingkat Stress Dengan Kadar Gula Darah Pada Penderita Diabetes Melitus di Wilayah RW 7 Kelurahan Simokerto Kecamatan Simokerto Surabaya

\begin{tabular}{|c|c|c|c|c|c|c|c|}
\hline \multirow[b]{2}{*}{$\begin{array}{c}\text { Tingk } \\
\text { at } \\
\text { Stres }\end{array}$} & \multicolumn{6}{|c|}{ Kadar Gula } & \multirow[b]{2}{*}{$\begin{array}{c}\text { Jum } \\
\text { lah }\end{array}$} \\
\hline & $\begin{array}{c}\text { Hipo } \\
\text { glike } \\
\text { mia }\end{array}$ & $\%$ & $\begin{array}{c}\text { No } \\
\text { rm } \\
\text { al }\end{array}$ & $\%$ & $\begin{array}{c}\text { Hiper } \\
\text { glike } \\
\text { mia }\end{array}$ & $\%$ & \\
\hline $\begin{array}{l}\text { Tidak } \\
\text { Stres }\end{array}$ & 3 & $\begin{array}{l}7 \\
\%\end{array}$ & 19 & $\begin{array}{l}4 \\
2 \\
\%\end{array}$ & 0 & $\begin{array}{l}0 \\
\%\end{array}$ & $\begin{array}{c}22 \\
(49 \\
\%)\end{array}$ \\
\hline $\begin{array}{c}\text { Stres } \\
\text { Ringa } \\
\mathrm{n}\end{array}$ & 0 & $\begin{array}{l}0 \\
\%\end{array}$ & 0 & $\begin{array}{l}0 \\
\%\end{array}$ & 9 & $\begin{array}{l}2 \\
0 \\
\% \\
\end{array}$ & $\begin{array}{c}9 \\
(20 \\
\%) \\
\end{array}$ \\
\hline $\begin{array}{c}\text { Stres } \\
\text { Seda } \\
\text { ng }\end{array}$ & 0 & $\begin{array}{l}0 \\
\%\end{array}$ & 0 & $\begin{array}{l}0 \\
\%\end{array}$ & 11 & $\begin{array}{l}2 \\
4 \\
\% \\
\end{array}$ & $\begin{array}{c}11 \\
(24 \\
\%) \\
\end{array}$ \\
\hline $\begin{array}{l}\text { Stres } \\
\text { Berat }\end{array}$ & 0 & $\begin{array}{l}0 \\
\%\end{array}$ & 0 & $\begin{array}{l}0 \\
\%\end{array}$ & 3 & $\begin{array}{l}7 \\
\%\end{array}$ & $\begin{array}{c}3 \\
(7 \% \\
)\end{array}$ \\
\hline & & & tal & & & & $\begin{array}{c}45 \\
(100 \\
\%)\end{array}$ \\
\hline
\end{tabular}

Hasil Uji Spearmen $\mathrm{p}=0,00$

Correlation Coefficient $r=0,909$

Berdasarkan Tabel 7 Hasil Uji Spearman menunjukkan tingkat signifikansi $p<0,05$ sehingga H0 ditolak yaitu terdapat hubungan yang sangat kuat antara tingkat stress dengan kadar gula darah pada penderita Diabetes Mellitus (DM) dengan Correlation Coefffient $\mathrm{r}=0,909$.

\section{PEMBAHASAN}

1. Identifikasi Tingkat Stress

Hasil penelitian yang dilakukan di $\begin{array}{lllll}\text { Wilayah } & \text { RW } & 7 & \text { Kelurahan } & \text { Simokerto }\end{array}$ Kecamatan Simokerto Surabaya pada tanggal 19 - 31 Maret 2018 tentang tingkat stress menunjukan bahwa hampir sebagian besar memiliki tingkatan stress dengan tingkat tidak stress (49\%), tingkat stress sedang (25\%), tingkat stress ringan (20\%), serta tingkat stress berat $(6 \%)$

Stress adalah perasaan yang dialami seseorang apabila menerima sebuah tekanan tekanan. Tekanan atau tuntutan yang diterima datang dalam bentuk pencapaian prestasi akademik, pemenuhan harapan keluarga dan mengekalkan jalinan perhubungan ${ }^{1 .}$ Lingkungan menjadi pengaruh yang cukup besar terjadinya stress pada individu. Ketidakseimbangan kemampuan dalam menghadapi tekanan akan mengakibatkan seseorang berada dalam kondisi stress ${ }^{9}$.

Stressor merupakan penyebab stress yang paling sering terjadi. Stressor muncul dapat sendiri-sendiri atau dapat pula bersamaan, salah satunya stressor kimia yang timbul dari luar tubuh dapat berupa obat dan pengobatan. Reaksi individu terehadap stress dapat berpengaruh terhadap tinggi atau rendahnya stress yang diperoleh individu misalnya factor perkembangan. Usia dan tahap perkembangan mempengaruhi dampak dari stress yang dialami masing - masing individu? .

Hasil penelitian yang didapat dilihat bahwa hampir sebagian besar responden memiliki tingkat stress dengan kategori tidak stress. Penderita DM yang diteliti berdasarkan lama menderita diabetes mellitus sekitar $1-5$ tahun sejumlah 24 (53\%), semakin lama seseorang menderita diabetes mellitus maka semakin rendah tingkat stress yang dialami karena mereka sudah terbiasa akan proses pengobatan yang dilakukan daridapa seseorang yang baru menderita diabetes mellitus. Berdasarkan usia responden didapatkan paling banyak berusia $>50$ tahun sujumlah 22 orang 
(49\%). Usia produktif $30-50$ tahun merupakan usia dewasa lanjut yang digunakan untuk bekerja lebih keras dan beraktivitas tinggi sehingga memungkinkan untuk mendapatkan stress yang tinggi, sedangkan pada usia $>50$ tahun seseorang tinggal menyesuaikan diri dengan apa yang telah didapatkan di masa tua. Berdasarkan tingkat pendidikan responden didapatkan paling banyak pada pendidikan terakhir SMA sebanyak 21 orang (47\%). Semakin tinggi pendidikan seseorang maka akan lebih mudah dalam mengatasi stress di dalam dirinya, hal ini dikarenakan pengetahuannya juga akan lebih baik daripada yang berpendidikan rendah. Stress dapat terjadi apabila seseorang memiliki tingkat pengetahuan yang rendah sehingga dapat memicu terjadinya stressor pada individu.

Tingkat stress dapat didukung oleh factor usia, pendidikan terakhir, dan lama menderita diabetes mellitus. Namun tingkat stress juga dapat dipengaruhi oleh bagaimana setiap individu memanejemen stress yang terjadi didalam tubuhnya. Gangguan atau kekacauan mental yang muncul dari seseorang disebabkan kurang mampu dalam melakukan manajemen stress secara efektif, misalnya mengidentifikasi kebiasaan atau sesuatu yang menyebabkan stress, mengganti kebiasaan yang dapat menyebabkan stress tersebut/ atasi stress yang tidak sehat, bersosialisasi dengan orang lain, menyediakan waktu untuk bersantai, dan gaya hidup sehat.

2. Identifikasi Kadar Gula Darah

Hasil penelitian yang dilakukan di Wilayah RW 7 Kelurahan Simokerto Kecamatan Simokerto Surabaya pada tanggal 19 - 31 Maret 2018 tentang kadar gula darah menunjukan bahwa sebagian besar memiliki niliai kadar gula dengan kategori Hiperglikemia (51\%), dengan kategori Normal (42\%), dan kategori Hipoglikemia (7\%).

Diabetes Mellitus (DM) merupakan kelompok penyakit metabolik yang ditunjukkan oleh kadar glukosa dalam darah yang tinggi (hiperglikemia) karena defek kerja insulin, atau defek sekresi insulin. DM adalah suatu gangguan metabolisme karbohidrat, protein dan lemak akibat dari ketidak seimbangan antara ketersediaan insulin dengan kebutuhan insulin.
Gangguan tersebut dapat berupa ketidakadekuatan atau kerusakan pada reseptor insulin, kerusakan insulin sebelum bekerja, gangguan pengeluaran insulin oleh sel beta pankreas dan produksi insulin yang tidak aktif defisiensi insulin absolut. 1 .

Hasil penelitian dapat dilihat bahwa sebagian besar responden mengalami hiperglikemia (51\%). Penderita DM yang diteliti berdasarkan tingkat umur paling banyak diatas 50 tahun keatas dengan semakin betarmbahnya umur, kemampuan sel jaringan mengambil glukosa darah semakin menurun. Berdasarkan jenis kelamin penderita DM lebih banyak terjadi pada perempuan sebanyak 29 orang $(65 \%)$ hal ini dikarenakan pola gaya hidup yang kurang sehat dengan mengkonsumsi makanan manis tanpa diimbangi dengan olahraga yang teratur sehingga menyebabkan peningkatan kadar gula darah pada perempuan daripada laki - laki.

3. Identifikasi Hubungan Tingkat Stress dengan Kadar Gula Darah

Hasil penelitian berdasarkan uji statistic hubungan tingkat stress dengan kadar gula darah pada penderita diabetes mellitus di $\begin{array}{lllll}\text { Wilayah } & \text { RW } & 7 & \text { Kelurahan } & \text { Simokerto }\end{array}$ Kecamatan Simokerto Surabaya pada tanggal 19 - 31 Maret 2018 menunjukan bahwa tingkatan tidak stress dengan karakteristik kadar gula darah hipoglikemia yaitu 3 orang $(7 \%)$, tingkatan tidak stress dengan karakteristik kadar gula darah normal yaitu 19 orang (42\%), tingkatan stress ringan dengan karakteristik kadar gula darah hiperglikemia yaitu 9 orang (20\%), tingkatan stress sedang dengan karakteristik kadar gula darah hiperglikemia yaitu 11 orang (42\%), tingkatan stress berat dengan karakteristik kadar gula darah hiperglikemia yaitu 3 orang (7\%).

Hasil uji statistik menyimpulkan ada hubungan antara tingkat stress dengan kadar gula darah pada penderita diabetes mellitus dimana $\mathrm{p}<0,05$ yaitu $\mathrm{H} 1$ diterima artinya terdapat hubungan yang signifikan antara tingkat stress dengan kadar gula darah, hubungan tersebut memiliki kekuatan sangat kuat berdasarkan nilai $r=0,909$.

Stres merupakan situasi dimana tuntutan non-spesifik mengharuskan individu untuk 
berespon atau melakukan tindakan. Ketidaksesuaian antara kemampuan yang dimiliki dan besarnya tuntutan dapat memunculkan stress terhadap individu ${ }^{4}$. Perubahan latihan, penggunaan obat, pola makan yang biasa dipatuhi sering dialami oleh penderita diabetes mellitus yang mengalami stress. Hal tersebut dapat menyebabkan hiperglikemia ${ }^{12 .}$

Hasil penelitian ini menunjukkan bahwa ada hubungan yang sangat kuat antara tingkat stress dengan kestabilan kadar gula darah, apabila tingkatan stress menunjukan dalam kategori stress berat maka akan terjadi ketidakstabilan kadar gula darah. Oleh karena itu, pentingnya dalam memanejemen stress pada penderita diabetes mellitus dalam pengendalian kadar gula darah sehingga kadar gula darah tetap terkontrol.

Berdasarkan hasil yang didapat bahwa 9 responden mengalami stress ringan masuk dalam kategori hiperglikemia. Hal tersebut dikarenakan peneliti memakai kriteria diagnosis untuk gangguan kadar gula darah yang menyatakan kadar gula darah normal memiliki nilai $80-140 \mathrm{mg} / \mathrm{dL}$. Sedangkan 6 diantaranya memiliki nilai kadar gula darah kurang dari 200 $\mathrm{mg} / \mathrm{dL}^{7}$.

\section{SIMPULAN}

Hasil tingkat stress pada penderita Diabetes Melitus didapatkan, hampir sebagian besar tingkat stress pada penderita diabetes mellitus di wilayah RW 7 Kelurahan Simokerto Kecamatan Simokerto Surabaya dalam kategori tidak stress. Hasil kadar glukosa pada penderita Diabetes Melitus didapatkan, sebagian besar kadar gula darah pada penderita diabetes mellitus di wilayah RW 7 Kelurahan Simokerto Kecamatan Simokerto dalam kategori hiperglikemia. Hasil uji statistic dengan korelasi dari spearman rho diperoleh nilai signifikasi < 0,05 yaitu 0,00 , hal ini menunjukkan terdapat hubungan tingkat stress dengan kadar gula darah pada penderita Diabetes Melitus maka H1 diterima. $r=0,909$ yang berarti hubungan tersebut bersifat positif dan berkekuatan sangat kuat.

\section{REFERENSI}

Carolin. 2010. Gambaran Tingkat Stres pada Mahasiswa Kedokteran Universitas Sumatera Utara [skripsi]. Medan : Fakultas Kedokteran Universitas Sumatera Utara.

Damayanti, Santi. 2015. Diabetes Mellitus \& Penatalaksanaan Keperawaran. Yogyakarta : Nuha Medika.

Guyton. 2008. Buku Ajar Fisiologi Kedokteran. Alih Bahasa Irawati Setiawan. Jakarta : EGC.

Hans, T. 2009. Kiss Diabetes Goodbye 7 Langkah Mencegah Diabetes. Surabaya : Jaring Pena.

Lazarus, R. d. (2012). Stress, Appraisal, and Coping. New York: Springer Publishing Company

Notoatmodjo, S. 2005. Promosi Kesehatan Teori dan Aplikasi. Jakarta: PT Rineka Cipta.

Perry, Potter \&. 2006. Buku Ajar Fundamental Keperawatan. Jakarta : EGC.

Price, A. 2006. Patofisiologi: Konsep Klinis Proses-Proses Penyakit, Edisi 6, (terjemahan), Peter Anugerah. Jakarta: EGC.

Rasmun. 2004. Stres, Koping dan Adaptasi. Jakarta : Sagung Seto.

Setiawan, B. S. 2007. Buku Ajar Ilmu Penyakit Dalam. Surabaya: Airlangga University Press.

Smeltzer S. C \& Bare, Brunner \& Suddarth. 2002. Keperawatan Medikal Bedah. (terj.) Edisi 8 Volume 2 alih bahasa H.Y kuncura, Andy Hartono, Monica Ester, Yasmin Asih. Jakarta : EGC.

Sukardji, K. (2002). Penatalaksanaan Gizi Pada Diabetes Melitus. Dalam Penatalaksanaan Diabetes Melitus Terpadu. Pusat Diabetes dan Lipid RSUPN Dr. Cipto Mangunkusumo. Jakarta: FKIK. 